\title{
Cardiac and vascular effects of diltiazem, dobutamine and amrinone, drugs used after myocardial revascularization
}

A. Gómez-Alvis ${ }^{1}$, A. Rebolledo ${ }^{1}$, V. Milesi ${ }^{1}$, J. Raingo ${ }^{1}$, N. Sanz ${ }^{2}$, J. Tommasi², A. Drago ${ }^{2}$, G. Rinaldi ${ }^{1}$ and A. Grassi ${ }^{1}$

\author{
'Departamento de Ciencias Biológicas, Facultad de Ciencias Exactas, \\ Universidad Nacional de La Plata, La Plata, Argentina \\ ${ }^{2}$ Hospital San Juan de Dios, Ministerio de Salud de la Provincia de Buenos Aires, \\ La Plata, Argentina
}

\author{
Correspondence \\ A. Grassi \\ Facultad de Ciencias Exactas \\ 47 y 115 \\ 1900 La Plata \\ Argentina \\ Fax: +54-221-422-3409 \\ E-mail: \\ agrassi@nahuel.biol.unlp.edu.ar \\ J. Raingo is the recipient of a \\ fellowship from Universidad \\ Nacional de La Plata. A. Rebolledo, \\ V. Milesi, G. Rinaldi, and \\ A. Grassi are members of Carrera \\ del Investigador Científico y \\ Tecnológico of CONICET (PIP \\ \#4708).
}

Received July 15, 2003 Accepted February 19, 2004

\begin{abstract}
Hemodynamic care during postoperative management of myocardial revascularization should include vasorelaxing drugs to insure adequate graft and coronary flow, and stimulation of stroke volume to maintain vascular perfusion pressure. We tested the cardiac (inotropic and lusitropic) and vascular (relaxant) effects of diltiazem ( $0.1 \mathrm{nM}$ to $0.1 \mathrm{mM})$, dobutamine ( $10 \mu \mathrm{M}$ to $10 \mathrm{mM})$ and amrinone $(10 \mu \mathrm{M}$ to 1 $\mathrm{mM}$ ) on isolated rat atria and thoracic aorta, and also on isolated Dobutamine produced a maximal positive inotropic effect $\left(+\mathrm{dF} / \mathrm{dt}_{\max }\right.$ $=29 \pm 7 \%)$ at its $\mathrm{ED}_{50}$ for aortic relaxation $(88 \pm 7 \mu \mathrm{M})$. Conversely, at their $\mathrm{ED}_{50}$ for aortic relaxation diltiazem depressed myocardial contractility and amrinone did not exhibit myocardial effects. In HSV and HMA contracted with $80 \mathrm{mM}$ potassium, diltiazem and dobutamine (but not amrinone) had a vasorelaxant activity similar to that in rat aorta. Norepinephrine-contracted human vessels were significantly more sensitive than potassium-contracted vessels to the relaxant effect of amrinone $\left(\mathrm{ED}_{50} \mathrm{HMA}=15 \pm 5 \mu \mathrm{M}, \mathrm{ED}_{50} \mathrm{HSV}=72 \pm 31 \mu \mathrm{M}\right.$, $\mathrm{P}<0.05)$. We conclude that at concentrations still devoid of myocardial effects dobutamine and amrinone are effective dilators in graft segment vessels and rat aorta contracted by membrane depolarization. If the difference between aortic and myocardial tissue still holds in human tissues, at the appropriate concentrations these drugs should be expected to improve cardiac performance while still contributing to the maintenance of graft patency.
\end{abstract}

Key words

- Amrinone

- Dobutamine

- Diltiazem

- Saphenous vein

- Mammary artery

\section{Introduction}

The postoperative management of patients who undergo open heart surgery and receive autologous bypass grafts may require the use of vasodilating drugs to maintain adequate coronary and graft perfusion flow. Usually, these patients also present left ventricular dysfunction and, if graft vasospasm develops, the use of vasodilators with negative inotropic effects, i.e., calcium channel blockers, angiotensin-converting enzyme in- 
hibitors or long-lasting nitrates, might cause further impairment of myocardial contractility. On the other hand, these patients, often hypotensive and hypoperfused during the immediate postoperative period, are treated with vasoconstrictors such as norepinephrine that would reduce graft and coronary perfusion. Therefore, the drugs of choice to treat the hemodynamic malfunction of these patients seem to be those that cause: i) vasorelaxation to maintain adequate graft and coronary flow, and ii) stimulation of cardiac stroke volume to maintain vascular perfusion pressure.

Phosphodiesterase type III (PDE-III) inhibitors and dobutamine are used clinically as vasodilating and myocardial positive inotropic drugs. They share at least one intracellular signaling pathway, the elevation of intracellular levels of cAMP, to produce both vascular and cardiac effects. Since species and vessel specificity has been reported for the vascular effects of PDE-III inhibitors (1) it is of potential clinical importance to evaluate the responsiveness of vessels used as coronary grafts to these drugs. Milrinone has been reported to be a strong vasodilator in human mammary artery (HMA) contracted either with high external potassium or with other receptor-mediated agonists (2). In rat aorta and in HMA, relaxation induced by milrinone has been demonstrated to be endothelium-independent; while amrinone has both endothelium-dependent and -independent vasodilatory effects in rat aorta (3), as well as in the human forearm vessels $(4,5)$. The dependence of PDE-III inhibitors on endothelium to produce vasodilation is controversial. Stimulation of nitric oxide (NO) production by PDE-III inhibitors may be implicated not only because of their ability to reduce pulmonary and systemic resistance, but also to inhibit both smooth muscle cell proliferation and platelet aggregation (6). Therefore, the benefits of using these drugs could be extended to the possible prevention of the develop- ment of "graft disease".

The aim of the present study was to compare the relaxant response of specimens taken from the most commonly used vessel grafts, the internal HMA and the human saphenous vein (HSV), to three clinically useful vasodilator drugs, diltiazem, dobutamine and amrinone. We also compared the vasorelaxation induced by all three drugs in the rat aorta and related this effect to their inotropic action on the isolated rat atria. These in vitro animal experiments permitted us to estimate the vascular and myocardial modifications that can be expected at concentrations corresponding to the $\mathrm{ED}_{50}$ for each drug.

\section{Material and Methods}

\section{Human sample preparation}

The vessels employed in this study were obtained from patients undergoing primary coronary artery bypass surgery at the Service of Cardiothoracic Surgery of the Hospital San Juan de Dios, Ministerio de Salud de la Provincia de Buenos Aires, La Plata, Argentina. The preparations could be either saphenous vein or mammary artery and were classified as surgical specimens and thus exempted from patient consent requirements. After the end of bypass surgery the remnant segments were transported to our laboratory in ice-cold $0.9 \% \mathrm{NaCl}$ and studied within $24 \mathrm{~h}$.

\section{Rat aorta preparation}

Sprague-Dawley female rats (45-60 days old) were anesthetized with ethyl ether and the thoracic aorta was removed rapidly. The vessels were placed on a Petri dish filled with oxygenated $\left(5 \% \mathrm{CO}_{2}\right.$ and $\left.95 \% \mathrm{O}_{2}\right) \mathrm{Krebs}$ solution (see composition further on), cleaned of adherent connective tissue, and cut into 24-mm long rings. Special care was taken not to damage the endothelial layer or to overdistend the vessel during this procedure. 


\section{Contractile studies of vessel segments}

Contractile responses were determined in a water-jacketed organ bath filled with a modified Krebs solution of the following composition: $130 \mathrm{mM} \mathrm{NaCl}, 4.7 \mathrm{mM} \mathrm{KCl}$, $1.17 \mathrm{mM} \mathrm{Na}_{2} \mathrm{HPO}_{4}, 1.16 \mathrm{mM} \mathrm{MgSO}_{4}, 24.0$ $\mathrm{mM} \mathrm{HCO}{ }_{3} \mathrm{Na}, 1.6 \mathrm{mM} \mathrm{CaCl}_{2}$, and $11 \mathrm{mM}$ glucose. The organ bath was kept at $37^{\circ} \mathrm{C}$ and bubbled with a mixture of $5 \% \mathrm{CO}_{2}$ and $95 \% \mathrm{O}_{2}, \mathrm{pH}$ 7.4. The ring was suspended gently between two stainless steel wires that could be separated with a micrometer to achieve the desired passive force. The lower wire was fixed to a vertical plastic rod immersed in the organ bath, while the upper one was attached to a force transducer (Grass FT.03D, West Warwick, RI, USA, or Letica TRI-201, Barcelona, Spain). The output of the transducer was amplified and fed into an analog-digital board (DT16EZ, Data Translation, Inc., Marlboro, MA, USA) mounted on a desktop computer. On-line recordings and files for later processing were obtained with an appropriate software (Labtech Notebook Pro, Laboratory Technology Corp., Wilmington, MA, USA). A passive tension of $2 \mathrm{~g}$ was applied, and the rings were allowed to stabilize for $1 \mathrm{~h}$, being washed out with fresh solution every 20 min.

High potassium solution was used to elicit contractions by depolarization of the plasma membrane. The Krebs solution contained 80 $\mathrm{mM} \mathrm{KCl}$ and the appropriate reduction in $\mathrm{NaCl}$ in order to keep osmolarity unchanged. In some experiments, contraction was produced by exposure to $1 \mu \mathrm{M}$ norepinephrine (NE) instead of high potassium. Once contractions reached a steady state force, additive dose-response curves were constructed for diltiazem $(0.1 \mathrm{nM}$ to $0.1 \mathrm{mM})$, dobutamine $(10 \mu \mathrm{M}$ to $10 \mathrm{mM})$ and amrinone (10 $\mu \mathrm{M}$ to $1 \mathrm{mM}$ ). Results are reported as percent of the maximal force elicited by $80 \mathrm{mM}$ $\mathrm{KCl}$ and the $\mathrm{ED}_{50}$ value was calculated from the dose-response curve.

\section{Isolated rat atrium preparation}

Male Sprague-Dawley rats (200-250 g) were used. The rats were anesthetized with ethyl ether and the heart was quickly removed and placed in bicarbonate-buffered saline equilibrated with $5 \% \mathrm{CO}_{2}-95 \% \mathrm{O}_{2}$ at room temperature. The spontaneously beating atria were dissected and the left atrium was mounted on an organ bath with the free end connected to a force transducer (Letica TRI 201). The organ bath contained bicarbonate-buffered saline of the following composition: $5 \mathrm{mM} \mathrm{KCl}, 1 \mathrm{mM} \mathrm{MgSO}{ }_{4}, 1 \mathrm{mM}$ $\mathrm{NaH}_{2} \mathrm{PO}_{4}, 111 \mathrm{mM} \mathrm{NaCl}, 1.35 \mathrm{mM} \mathrm{CaCl}{ }_{2}$, $24 \mathrm{mM} \mathrm{NaHCO}_{3}$, and $11 \mathrm{mM}$ glucose. The solution was equilibrated with $5 \% \mathrm{CO}_{2}$ and $95 \% \mathrm{O}_{2}, \mathrm{pH} 7.4$, thermostated at $37^{\circ} \mathrm{C}$.

After being attached to the transducer the atrium was stretched until reaching maximal developed force and stabilized for $30 \mathrm{~min}$, with the bath solution being replaced every $10 \mathrm{~min}$. The atrium was paced with an electrical field stimulator at 168 beats/min. After the stabilization period, additive dose-response curves were constructed for diltiazem, dobutamine and amrinone. Isometric contractions were recorded from the amplified output of the transducer fed to an analog-digital board (see above) mounted on a desktop computer. Online recordings and files were obtained with an appropriate software (Snapshot Storage Scope, EHM Data Corporation, Bolingbrook, IL, USA) for later processing. High speed records $(0.25 \mathrm{~s} /$ frame $)$ were used in order to measure peak developed force $(\mathrm{F})$ and, on its first derivative $(\mathrm{dF} /$ $\mathrm{dt})$, maximal velocity of contraction $(+\mathrm{dF} /$ $\left.\mathrm{dt}_{\max }\right)$ and maximal velocity of relaxation

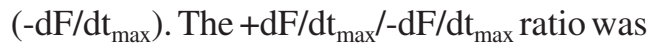
calculated to evaluate the relative effect of each intervention on velocities of contraction and relaxation, with its decrease being considered evidence of a positive lusitropic (or relaxant) effect and its increase being considered evidence of a negative lusitropic (or antirelaxant) effect $(7,8)$. 


\section{Statistical analysis}

Data are reported as means \pm SEM. Differences between means were determined by the Student $t$-test for unpaired samples (two groups) or by analysis of variance (more
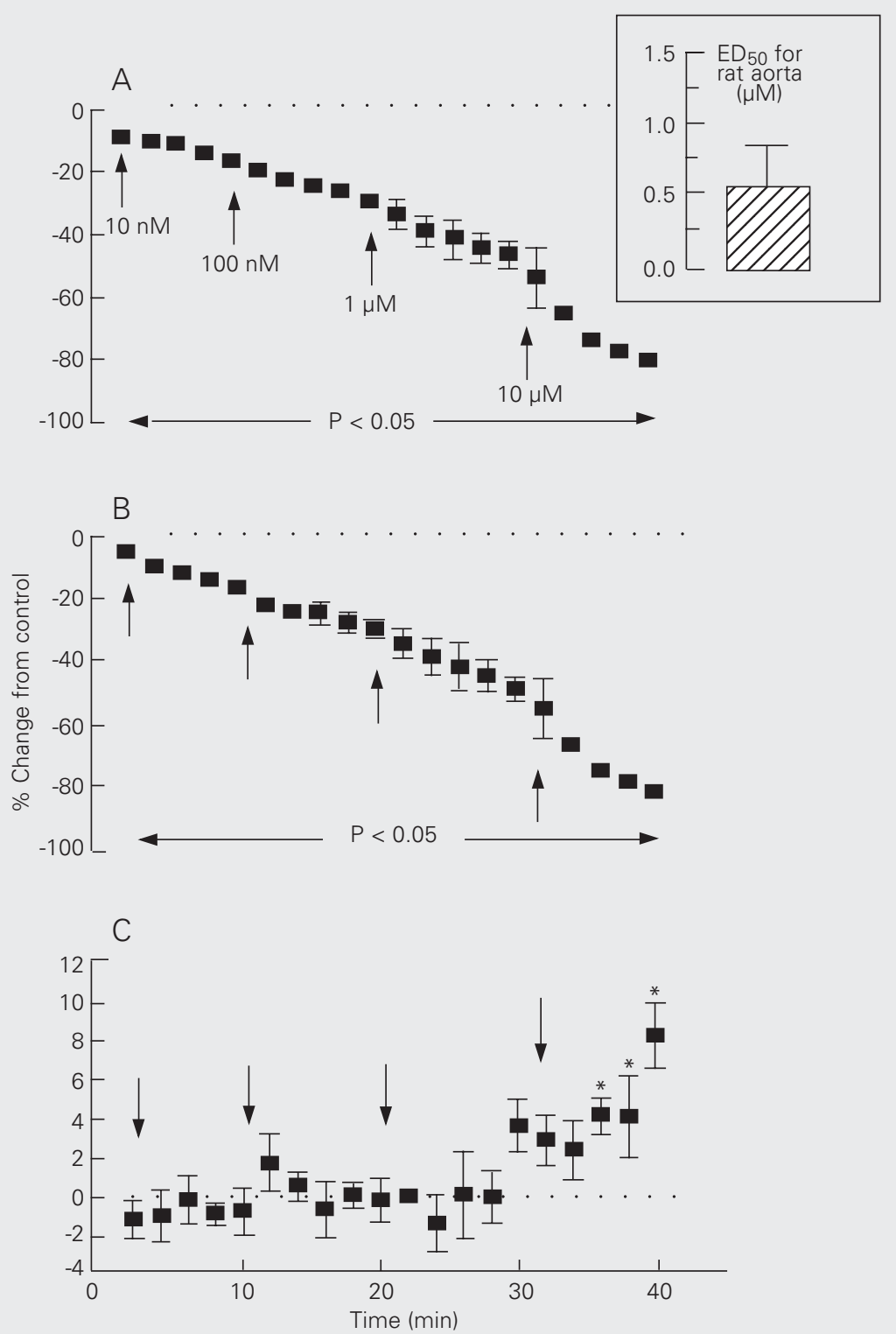

Figure 1. Effects of diltiazem ( $10 \mathrm{nM}$ to $10 \mu \mathrm{M}$, at the time indicated by arrows) on isolated rat atria $(N=5)$ paced at 168 beats/min. Data are reported as means \pm SEM of the percent changes from control values recorded at the times indicated. Diltiazem depressed the $+\mathrm{dF} /$ $\mathrm{dt}_{\max }(\mathrm{A})$ and $-\mathrm{dF} / \mathrm{dt}_{\max }(\mathrm{B})$, and at the concentration of $10 \mu \mathrm{M}$ produced a significant increase in the $+\mathrm{dF} / \mathrm{dt}_{\max } / \mathrm{dF} / \mathrm{dt}_{\max }$ ratio $(\mathrm{C})$, indicating a negative lusitropic effect. ${ }^{*} \mathrm{P}<$ 0.05 compared to time 0 (Student $t$-test). Inset, $\mathrm{ED}_{50}$ to relax $\mathrm{KCl}$-contracted rat aorta. $+\mathrm{dF} /$ $\mathrm{dt}_{\max }$ and $-\mathrm{dF} / \mathrm{dt}_{\max }=$ maximal velocities of contraction and relaxation, respectively. than two groups), and significance was accepted when $\mathrm{P}<0.05$. The specific application of each method is indicated in the figure legends.

\section{Results}

\section{Atrial contractility and aortic relaxation in animal experiments}

Diltiazem $(10 \mathrm{nM}$ to $10 \mu \mathrm{M}, \mathrm{N}=5)$ produced a concentration-dependent depression of atrial contractility and relaxation evidenced by the decreases in $+\mathrm{dF}^{-\mathrm{dt}_{\max }}$ and $-\mathrm{dF} / \mathrm{dt}_{\max }$ values, respectively (Figure 1A,B). At high concentrations of diltiazem a negative lusitropic effect was indicated by the significant increase in the $+\mathrm{dF} / \mathrm{dt}_{\max } /-\mathrm{dF}_{\mathrm{dt}} \mathrm{d}_{\max }$ ratio (Figure $1 \mathrm{C}$ ). Rat aortic rings precontracted with $80 \mathrm{mM} \mathrm{KCl}$ were relaxed by diltiazem ( $10 \mathrm{nM}$ to $0.1 \mathrm{mM}, \mathrm{N}=8)$ with an $\mathrm{ED}_{50}$ of $0.56 \pm 0.26 \mu \mathrm{M}$ (Figure 1, inset). Myocardial contractility $\left(+\mathrm{dF} / \mathrm{dt}_{\max }\right)$ was depressed by $30 \pm 6 \%$ at $0.1 \mu \mathrm{M}$.

Dobutamine $(0.7 \mu \mathrm{M}$ to $0.14 \mathrm{mM}, \mathrm{N}=9)$ increased $+\mathrm{dF}^{\mathrm{d}} / \mathrm{dt}_{\max }$ and $-\mathrm{dF} / \mathrm{dt}_{\max }$ by about $30-40 \%$ and did not significantly affect the $+\mathrm{dF} / \mathrm{dt}_{\max } /-\mathrm{dF}_{\mathrm{dt}} \mathrm{d}_{\max }$ ratio in the rat atria (Figure $2 \mathrm{~A}, \mathrm{~B}$ and $\mathrm{C}$, respectively). Rat aortic rings contracted with $80 \mathrm{mM} \mathrm{KCl}$ were relaxed by dobutamine ( 0.1 to $0.6 \mathrm{mM}, \mathrm{N}=12$ ) with an $\mathrm{ED}_{50}$ of $88 \pm 7 \mu \mathrm{M}$ (Figure 2, inset), and the $\mathrm{ED}_{50}$ for aortic relaxation had a maximal positive inotropic effect on the atria (Figure 2A).

Amrinone $(10 \mu \mathrm{M}$ to $1 \mathrm{mM}, \mathrm{N}=6) \mathrm{did}$ not have positive inotropic effects on rat atria at 10 or $100 \mu \mathrm{M}$, but elicited similar percentile increases in $+\mathrm{dF} / \mathrm{dt}_{\max }$ and $-\mathrm{dF} /$ $\mathrm{dt}_{\max }$ at $1 \mathrm{mM}$, with no significant changes in the $+\mathrm{dF} / \mathrm{dt}_{\max } /-\mathrm{dF} / \mathrm{dt}_{\max }$ ratio (Figure $3 \mathrm{~A}$ to C). Aortic rings precontracted with $80 \mathrm{mM}$ $\mathrm{KCl}$ were relaxed by amrinone $(10 \mu \mathrm{M}$ to 1 $\mathrm{mM}, \mathrm{N}=12$ ) with an $\mathrm{ED}_{50}$ of $69 \pm 5 \mu \mathrm{M}$ (Figure 3, inset), a dose at which no positive inotropic effect was detected in isolated rat atria. 


\section{Relaxation in human vessels}

Amrinone had a relaxing action on both $\mathrm{KCl}$ - and NE-contracted vessels, as shown in Table 1. In the three vessels studied, the $\mathrm{ED}_{50}$ values were significantly lower for NEinduced contractions than for $\mathrm{KCl}$-induced contractions. In $\mathrm{KCl}$-induced contractions only, the relaxation induced by amrinone in HSV and HMA was significantly less intense than that produced in $\mathrm{KCl}$-contracted rat aorta (Table 1).

The relaxant effect of diltiazem, dobutamine and amrinone on HSV and HMA rings precontracted with $80 \mathrm{mM} \mathrm{KCl}$ is shown in Figure 4. Diltiazem relaxed HSV and HMA with similar $\mathrm{ED}_{50}$ values $(0.78 \pm 0.28 \mu \mathrm{M}, \mathrm{N}$ $=10$, and $1.70 \pm 0.60 \mu \mathrm{M}, \mathrm{N}=4$, respec tively). Dobutamine was more effective in relaxing the HMA than the HSV $\left(\mathrm{ED}_{50}\right.$ of $157 \pm 21, N=5$ and $390 \pm 91 \mu \mathrm{M}, \mathrm{N}=10$, respectively, $\mathrm{P}<0.05)$.

\section{Discussion}

Three vasodilating drugs commonly used in cardiovascular therapy were compared in terms of their ability to improve myocardial performance and to maintain the patency of the implanted grafts after graft surgery. Two of the three drugs, dobutamine and amrinone, relaxed the HSV, and HMA as well as the rat aorta and improved contractility in an isolated preparation of rat atria. Diltiazem, as expected, had a relaxant effect on human and rat vessels plus a negative inotropic action on rat atria.

A frequent situation in the postoperative period of patients receiving coronary grafts is that their blood pressure must be supported by administration of vasoconstricting agents, namely catecholamines. This therapy may aggravate the vasospasm that occurs before or after vascular anastomosis in reconstructive surgery. In addition, catecholamine tolerance results in down-regulation of beta-1 receptors (9) and long-term cate- cholamine therapy is often difficult to discontinue. Dobutamine is not a solution for this problem since its effects are mediated by beta adrenergic receptors; in addition, the enhancement of both stroke volume and heart rate that it produces is accompanied by an increase in myocardial oxygen consumption of about $30 \%(10,11)$. In the paced isolated rat atrium we found a significant positive inotropic effect produced by dobutamine. Dobutamine was less effective in vasodilating $\mathrm{KCl}$-precontracted $\mathrm{HSV}$ than $\mathrm{KCl}$-pre-

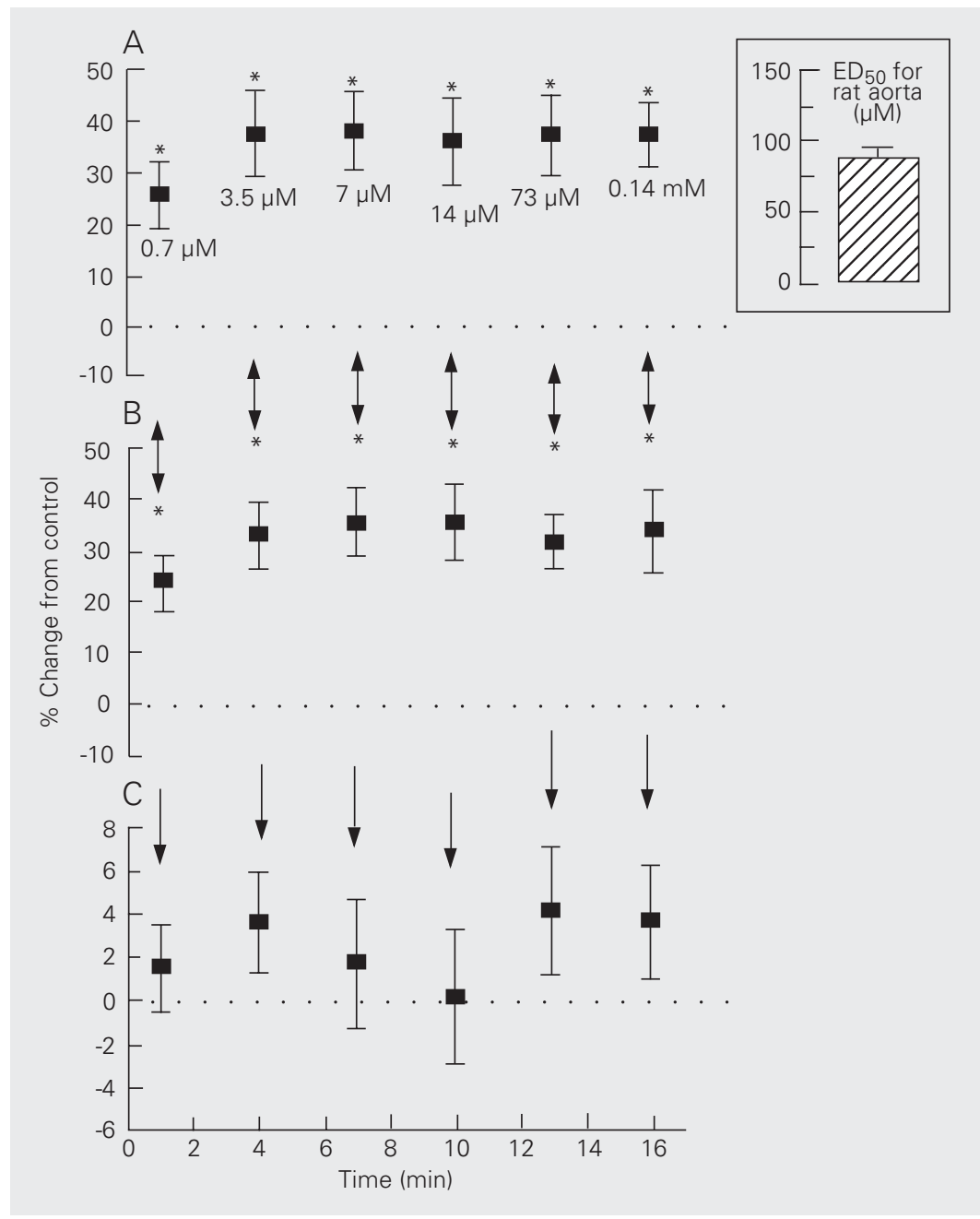

Figure 2. Effects of dobutamine $(0.7 \mu \mathrm{M}$ to $0.14 \mathrm{mM}$, at the time indicated by arrows) on isolated rat atria $(N=9)$ paced at 168 beats $/ \mathrm{min}$. Data are reported as means $\pm S E M$ of the percent changes from control values recorded at the times indicated. Dobutamine increased the $+\mathrm{dF} / \mathrm{dt}_{\max }(\mathrm{A})$ and $-\mathrm{dF} / \mathrm{dt}_{\max }(\mathrm{B})$ from the lowest concentration employed, but

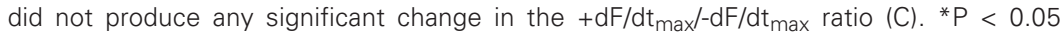
compared to time 0 (Student $t$-test). Inset, $\mathrm{ED}_{50}$ to relax $\mathrm{KCl}$-contracted rat aorta. $+\mathrm{dF} / \mathrm{dt}$ max and $-\mathrm{dF} / \mathrm{dt}_{\max }=$ maximal velocities of contraction and relaxation, respectively. 

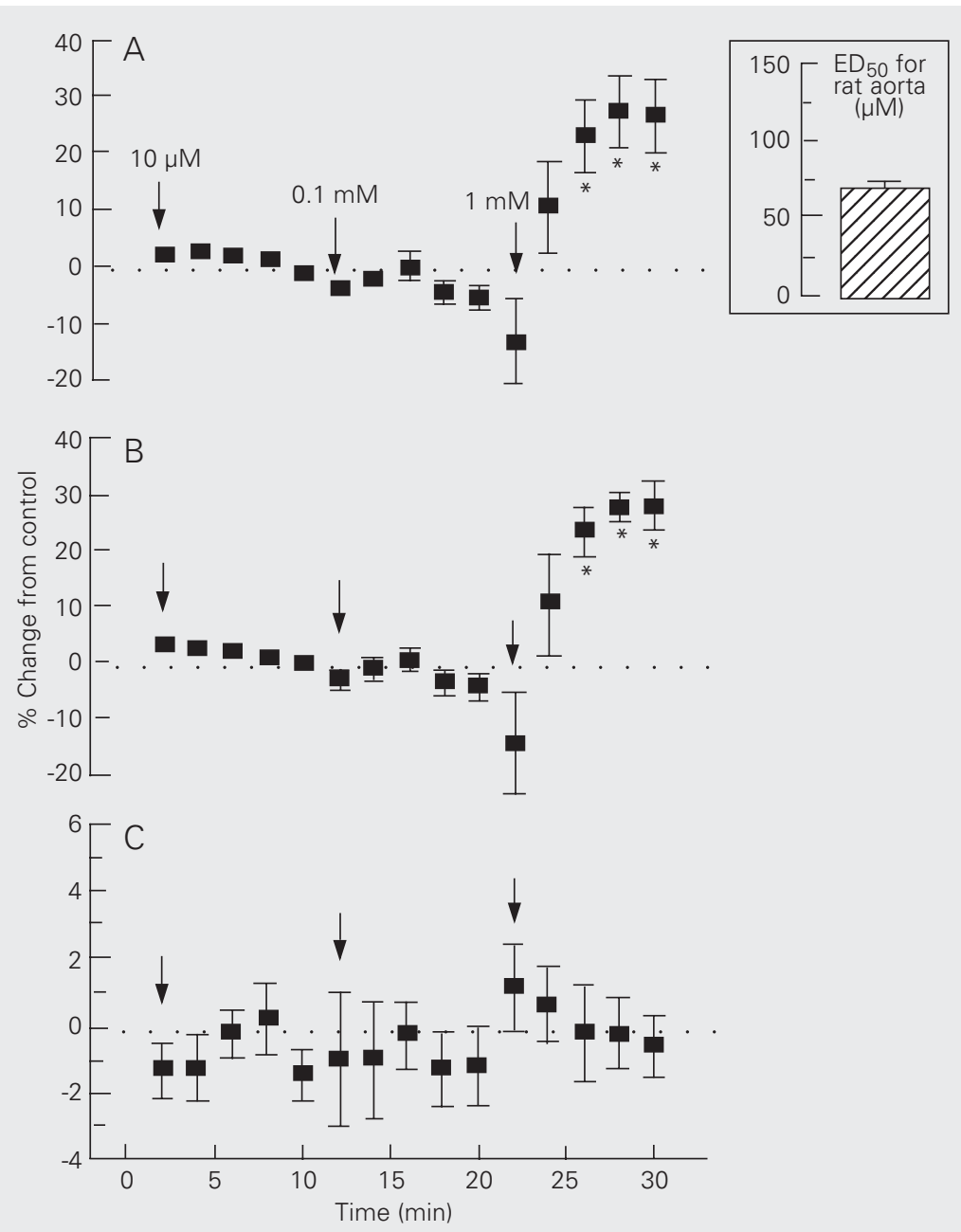

Figure 3. Effects of amrinone ( $10 \mu \mathrm{M}$ to $1 \mathrm{mM}$, at the time indicated by arrows) on isolated rat atria $(N=6)$ paced at 168 beats $/ \mathrm{min}$. Data are reported as means \pm SEM of the percent changes from control values recorded at the times indicated. At the highest concentration

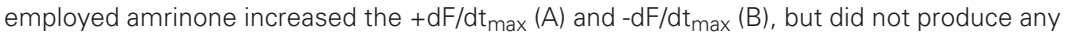
significant change in the $+\mathrm{dF} / \mathrm{dt}_{\max } /-\mathrm{dF} / \mathrm{dt}_{\max }$ ratio $(\mathrm{C}) .{ }^{*} \mathrm{P}<0.05$ compared to time 0 (Student $t$-test). Inset, $\mathrm{ED}_{50}$ to relax $\mathrm{KCl}$-contracted rat aorta. $-\mathrm{dF} / \mathrm{dt}$ max and $-\mathrm{dF} / \mathrm{dt} t_{\max }=$ maximal velocities of contraction and relaxation, respectively.

Table 1. Relaxant effect of amrinone on precontracted rings of rat aorta, human saphenous vein and human mammary artery.

\begin{tabular}{lccc}
\hline $\begin{array}{l}\text { Constricting } \\
\text { agent }\end{array}$ & \multicolumn{3}{c}{$\mathrm{ED}_{50}$ for amrinone $(\mu \mathrm{M})$} \\
\cline { 2 - 4 } & Rat aorta & Human saphenous vein & Human mammary artery \\
\hline $80 \mathrm{mM} \mathrm{KCl}$ & $69 \pm 5(\mathrm{~N}=12)$ & $210 \pm 27^{+}(\mathrm{N}=6)$ & $197 \pm 31^{+}(\mathrm{N}=4)$ \\
$1 \mu \mathrm{M} \mathrm{NE}$ & $41 \pm 3^{*}(\mathrm{~N}=12)$ & $72 \pm 31^{*}(\mathrm{~N}=7)$ & $15 \pm 5^{*}(\mathrm{~N}=4)$
\end{tabular}

${ }^{*} \mathrm{P}<0.05$ between $\mathrm{KCl}$ - and norepinephrine (NE)-contracted vessels (Student $t$-test) $+P<0.05$ between human vessels and rat aorta (Kruskal-Wallis ANOVA on ranks plus Dunn's test). contracted arterial vessels, namely rat aorta and HMA. Therefore, dobutamine will potentially reduce vasospasm at lower doses in arterial grafts than in venous grafts. In our animal experiments dobutamine showed the advantage of producing a maximal increase in atrial contractility even at the lowest doses exhibiting aorta relaxing effects. Since the $\mathrm{ED}_{50}$ for this effect was similar in rat aorta and in HMA it is possible that the positive inotropic effect on human tissue could be maximally achieved at these doses.

Milrinone treatment for several days has been successfully used to wean patients from catecholamine infusion (12). PDE-III inhibitors increase cardiac contractility and induce vasodilation that lowers the left and right ventricular filling pressure (13). Amrinone appears to be a more convenient choice than dobutamine because the pathway it uses to increase cAMP in myocytes is independent of beta adrenoceptor stimulation. In addition, amrinone predominantly increases stroke volume and does not affect myocardial oxygen consumption $(10,11)$. In the conscious and anesthetized dog, amrinone increases left ventricular performance, a fact that may be related to positive inotropic and lusitropic effects (14). Our data for rat tissues show that $1 \mathrm{mM}$ amrinone significantly enhanced contraction and relaxation of isolated atria while a positive lusitropic effect could not be detected through a significant decrease in the ratio values. The $\mathrm{ED}_{50}$ for aortic relaxation is about $70 \mu \mathrm{M}$. These results agree with those showing that both PDE-III inhibitors, amrinone and milrinone, induce larger vasodilatation compared to their positive inotropic effects (14). However, in the present experiments the $\mathrm{ED}_{50}$ of amrinone for relaxing the rat aorta contracted with high potassium was higher than that reported for rat aorta contracted with phenylephrine (about $4 \mu \mathrm{M}$ ) and lower than that necessary to relax rat airway smooth muscle $(360 \mu \mathrm{M})$. The vasodilation induced by amrinone in human vessels contracted with 80 
$\mathrm{mM} \mathrm{KCl}$ exhibited $\mathrm{ED}_{50}$ values of about 200 $\mu \mathrm{M}$, being five times higher than those reported with the clinical use of 10-40 $\mu \mathrm{M}$ $(15,16)$. However, the $\mathrm{ED}_{50}$ values required to relax NE-induced contractions were significantly lower than these values and close to the concentrations attained in clinical situations. Amrinone has both endothelium-dependent and endothelium-independent vasodilating effects on human vessels in vivo (5). We have reported that human vessel grafts exhibit endothelium-dependent relaxation in response to acetylcholine (17), but we cannot affirm that this response is quantitatively equal to that of the vessels in situ. Therefore, endothelial malfunction cannot be excluded as an explanation for the apparently lower sensitivity to amrinone of isolated HSV and HMA segments precontracted with high potassium compared with the sensitivity of aortic segments to this drug. In addition, most of the vessels were from patients that showed evidence of hypertension, hypercholesterolemia and/or atherosclerosis $(18,19)$, pathologies that often involve attenuated NO-dependent vasodilator responses (5). The topical use of amrinone to treat vasospasm in microvascular surgery could be better than that of lidocaine, a potent local anesthetic, since amrinone is a better vasodilator than lidocaine in rat femoral artery contracted with epinephrine (20). Another beneficial cardiovascular effect of amrinone is that it deactivates the reninangiotensin-aldosterone system, usually stimulated in patients with heart failure (12).

Comparing the relaxant effects of all three vasodilators tested, we observed that the $\mathrm{ED}_{50}$ values were always lower for rat aorta than for human vessels, except for dobutamine that relaxed with similar potency rat aorta and HMA. These results suggest species differences plus a potentially lower responsiveness to amrinone in human segments related to NO-dependent mechanisms of relaxation that may be blunted either by previous vascular pathology or by surgical
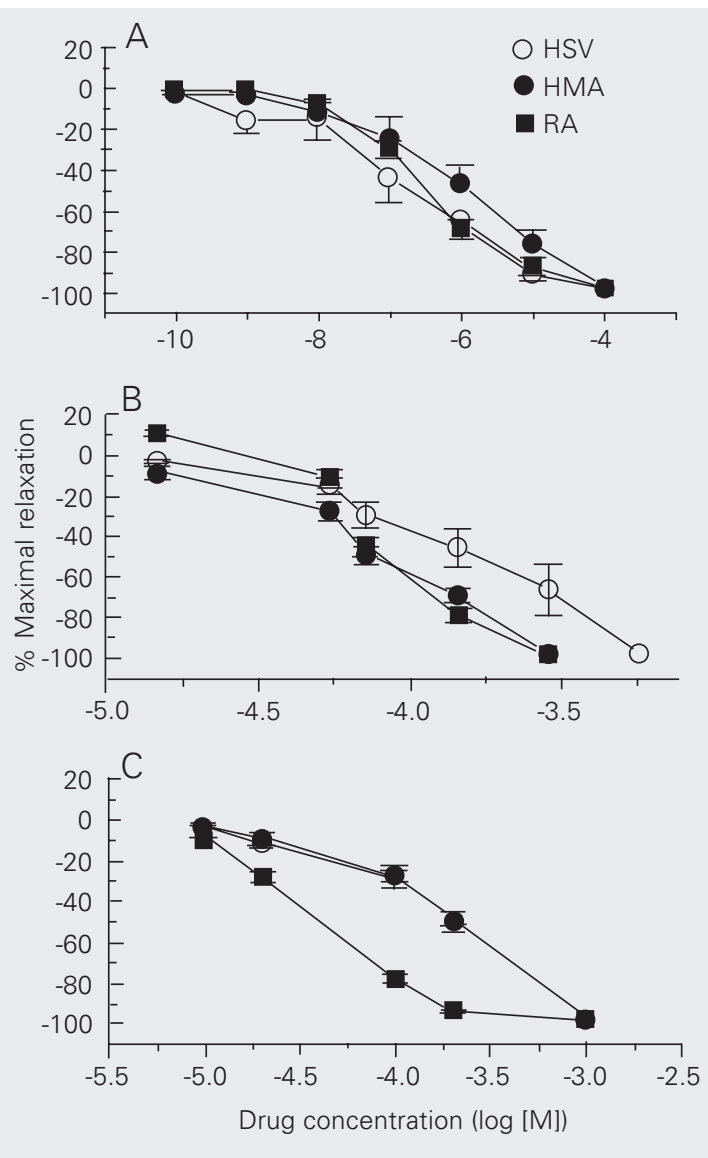

Figure 4. Effects of diltiazem $(A)$, dobutamine $(B)$ and amrinone $(C)$ on human saphenous veins (open circles, $\mathrm{N}=9,10$ and 6 , respectively), human mammary arteries (closed circles, $\mathrm{N}=4,5$ and 4 , respectively) and rat aortas (squares, $\mathrm{N}=$ 8, 12 and 12, respectively) precontracted by exposure to $80 \mathrm{mM} \mathrm{KCl}$. Data are reported as means \pm SEM of the percent changes from control values recorded at the concentrations indicated. $\mathrm{HMA}=$ human mammary artery, HSV = human saphenous vein, $\mathrm{RA}=$ rat aorta. manipulation of segment vessels. Dobutamine and amrinone increased rat atrial contractility at doses at which they had already achieved $100 \%$ of their vasodilatory effect in rat aorta. The $\mathrm{ED}_{50}$ for the relaxant action of dobutamine on HMA in vitro seems to be closer to the $\mathrm{ED}_{50}$ for positive inotropic effects. Nevertheless, both dobutamine or amrinone are proven to be effective dilators of graft segment vessels contracted by high $\mathrm{KCl}$ depolarization of the membrane and it is possible to expect a concomitant amelioration of cardiac performance when they are used to maintain graft patency in reperfusion surgery at appropriate concentrations.

\section{Acknowledgments}

The technical assistance of Mrs. Silvia Salemme is greatly appreciated. 


\section{References}

1. Dundore RL, Pagani ED, Bode DC, Bacon ER, Singh B, Lesher GY, Buchholz RA \& Silver PJ (1995). Species-dependent pharmacodynamic effects of the selective low Km cyclic AMP phosphodiesterase III inhibitors WIN 8993 and WIN 62005. Journal of Cardiovascular Pharmacology, 25: 14-21.

2. He G-W \& Yang Ch-Q (1996). Inhibition of vasoconstriction by phosphodiesterase III inhibitor milrinone in human conduit arteries used as coronary bypass grafts. Journal of Cardiovascular Pharmacology, 28: 208-214.

3. Mori K, Takeuchi S, Moritoki H, Tsuchiya K, Nakaya Y, Matsuoka S \& Kuroda $Y$ (1996). Endothelium-dependent relaxation of rat thoracic aorta by amrinone-induced nitric oxide release. European Heart Journal, 17: 308-316.

4. Vroom MB, Pfaffendorf M, van Wezel HB \& van Zwieten PA (1996). Effect of phosphodiesterase inhibitors on human arteries in vitro. British Journal of Anaesthesia, 76: 122-129.

5. Sakane T, Ishibashi $Y$, Shimada T, Takahashi N, Sugamori T, Hirano Y, Ohata S, Inoue SI, Nakamura K \& Murakami Y (2000). Impaired vasodilatation response to amrinone in the forearm of patients with congestive heart failure: Role of endothelium-derived nitric oxide. Journal of Cardiovascular Pharmacology, 36: 188-195.

6. Luscher TF (2001). Vascular protection: current possibilities and future perspectives. International Journal of Clinical Practice, 117 (Suppl): 3-6.

7. Grassi AO, Pérez Alzueta AD \& Cingolani HE (1977). Effect of isoproterenol on relation between maximal rate of contraction and maximal rate of relaxation. American Journal of Physiology, 233: H404-H409.

8. Vittone L, Grassi AO, Chiappe L, Argel M \& Cingolani HE (1981). Relaxing effects of pharmacological interventions increasing CAMP in rat heart. American Journal of Physiology, 240: H441-H447.

9. Bristow MR, Ginsburg R, Minobe W, Cubicciotti RS, Sageman WS, Lurie K, Billingham ME, Harrison DC \& Stinson EB (1982). Decreased catecholamine sensitivity and beta-receptor density in failing human hearts. New England Journal of Medicine, 307: 205-211.

10. Monrad ES, Baim DS, Smith HS \& Lanoue AS (1986). Milrinone, dobutamine and nitroprusside. Comparative effects on hemodynamics and myocardial energetics in patients with severe conges- tive heart failure. Circulation, 73 (Suppl II): 168-174.

11. Baim DS (1989). Effect of phosphodiesterase inhibition on myocardial oxygen consumption and coronary blood flow. American Journal of Cardiology, 63: 23A-25A.

12. Siostrzonek $P$, Koreny M, Delle-Karth G, Haumer M, Koller-Strametz $J$ \& Heinz G (2000). Milrinone therapy in catecholamine dependent critically ill patients with heart failure. Acta Anaesthesiologica Scandinavica, 44: 403-409.

13. Ludmer PL, Wright RF, Arnold MO, Ganz P, Braunwald E \& Colucci WS (1986). Separation of the direct myocardial and vasodilator actions of milrinone administered by an intracoronary infusion technique. Circulation, 73: 130-137.

14. Pagel PS, Hettrick DA \& Warltier DC (1993). Amrinone enhances myocardial contractility and improves left ventricular diastolic function in conscious and anesthetized chronically instrumented dogs. Anesthesiology, 79: 753-765.

15. Taira N (1988). Inotropic agents: new positive inotropic agents and their mechanism of action. In: Rand MJ \& Raper C (Editors), Pharmacology. Elsevier, Amsterdam, The Netherlands, 477-480.

16. Lawless ST, Zarisky A \& Miles M (1991). The acute pharmacokinetics and pharmacodynamics of amrinone in pediatric patients. Journal of Clinical Pharmacology, 31: 800-803.

17. Rinaldi G, Navia D, Vaccarino G, Segura E \& Albertal J (2000). Vasodilatadores en arterias radiales humanas aisladas. Medicina, 60: 420-426.

18. Milesi V, Rebolledo A, Ayala Paredes F, Sanz N, Tommasi J, Rinaldi $G$ \& Grassi A (1998). Mechanical properties of human saphenous veins from normotensive and hypertensive patients. Annals of Thoracic Surgery, 66: 455-461.

19. Milesi V, Rebolledo A, Gomez-Alvis A, Sanz N, Tommasi J, Drago A, Raingo J, Rinaldi GJ \& Grassi de Gende AO (2001). Aspectos estructurales y funcionales de la vena safena humana utilizada como puente aorto-coronario en la cirugía de revascularización miocárdica. Medicina, 61: 481-490.

20. Ichioka Sh, Nakatsuka T, Ohura N, Sato Y \& Harii K (2000). Topical application of amrinone (a selective phosphodiesterase III inhibitor) for relief of vasospasm. Journal of Surgical Research, 93: 149-155. 